2 Interactive Toxicity of Triclosan and Nano-TiO $\mathrm{No}_{2}$ Green Alga Eremosphaera

3 viridis in Lake Erie: A New Perspective based on Fourier Transform Infrared

4 Spectromicroscopy and Synchrotron-based X-ray Fluorescence Imaging Xiaying Xin, ${ }^{a}$ Gordon Huang, ${ }^{\mathrm{a}, *}$ Chunjiang $\mathrm{An}^{\mathrm{b}}$, Renfei Feng ${ }^{\mathrm{c}}$

6

$7 \quad{ }^{a}$ Institute for Energy, Environment and Sustainable Communities, University of

8 Regina, Regina, Canada S4S 0A2

$9 \mathrm{~b}^{\mathrm{b}}$ Department of Building, Civil and Environmental Engineering, Concordia

${ }^{\mathrm{c}}$ Canadian Light Source, Saskatoon, Saskatchewan, Canada S7N 2 V3

*Corresponding author: Tel: +1-306-5854095; Fax: +1-306-5854855; E-mail:

This SI file contains:

11Narrative section 


\section{MAERIALS AND METHODS}

\section{Triclosan adsorption and P25 photocatalysis experiments}

Adsorption and photocatalysis experiments were conducted in the dark and visible light conditions respectively, at room temperature $\left(23 \pm 1^{\circ} \mathrm{C}\right)$ by mixing $5 \mathrm{mg} / \mathrm{L} \mathrm{P} 25$ with different concentrations of triclosan ranging from 312.5 to $5000 \mu \mathrm{g} / \mathrm{L}$. The solution concentrations were determined at three time intervals including $12 \mathrm{~h}, 24$, and $72 \mathrm{~h}$. Hydrodynamic diameter and zeta potential of the P25 in aqueous phase in the presence of triclosan were measured by a Zetasizer Nano ZS (Malvern, United Kindom). For the quantification of residual triclosan, the aqueous phase was separated using centrifugation at $16128 \mathrm{~g}$ for $20 \mathrm{~min}$. The triclosan in supernatant was analyzed using Agilent 1260 liquid chromatograph equipped with a diode array detector (Santa Clara, CA, USA). A ZORBAZ XDB-C18 column $(250 \times 4.6 \mathrm{~mm}, 5 \mu \mathrm{m}$, Agilent $)$ was used for the analysis, with the oven temperature of $40^{\circ} \mathrm{C}$. The injection volume was $50 \mu \mathrm{L}$. The mobile phase consisting of $70: 30 \mathrm{v}: \mathrm{v} \%$ acetonitrile : water with flow rate of $0.8 \mathrm{~mL} / \mathrm{min}$. The wavelength used for detection was $214 \mathrm{~nm}$. The material in the pellet was used to determine the adsorption efficiency of triclosan by P25 through detecting the functional groups of triclosan on the surface of P25 using a FT-IR Bruker Tensor 27 spectroscopy (Bruker, Etlinger, Germany) equipped with an attenuated total reflectance.

\section{Determination of algal dry weight and Chlorophyll a/b concentrations}


Biomass dry weight was obtained by filtering a known volume of algal cells on a preweighed $0.45 \mu \mathrm{m}$ membrane filter. Filters with algal cells were dried for 24 hours at $60{ }^{\circ} \mathrm{C}$ and weighed to determine cell mass per volume of culture. The dry weight of cells was obtained by the difference between weight before and after drying.

Chlorophyll a (Chl a) and chlorophyll b (Chl b) were measured according to a modified method. ${ }^{1}$ Briefly, the algae were exposed to target components for $120 \mathrm{~h}$. $8 \mathrm{~mL}$ of algal suspension was centrifuged at $2268 \mathrm{~g}$ for $15 \mathrm{~min}$, after which the supernatant was discarded. The pellet was resuspended in $8 \mathrm{~mL} 90 \%$ ethanol with $1 \%$ $\mathrm{MgCO}_{3}$, incubated at $75^{\circ} \mathrm{C}$ for $5 \mathrm{~min}$ in the dark. $1 \% \mathrm{MgCO}_{3}$ was added to prevent the conversion of chlorophylls to phaeophytin. ${ }^{2}$ The extract was centrifuged at $2268 \mathrm{~g}$ for $15 \mathrm{~min}$, and the pellet was discarded. The absorbance of chlorophyll in the supernatant of the extract at 645 and $663 \mathrm{~nm}$ were analyzed by a Cary-300 double beam UV-visible spectrophotometer (Agilent Technologies, CA, USA). The content of Chl a and Chl b were calculated according to Jeffrey and Humphrey equation. ${ }^{3}$

\section{Cell morphology and ultrastructure observations}

Surface morphology of cells grown for $120 \mathrm{~h}$ was investigated using scanning electron microscopy (SEM). Samples were centrifuged at 10,000g for $15 \mathrm{~min}$, after which the supernatants were removed. The pellets were fixed in $2 \%$ glutaraldehyde in $50 \mathrm{mM}$ sodium cacodyate buffer $(\mathrm{NaCac}), \mathrm{pH} 7.2$ at room temperature for three hours, and then stored overnight in a refrigerator. Samples were subsequently washed in $50 \mathrm{mM}$ $\mathrm{NaCac}$ three times and further fixed in $1 \%$ Osmium tetroxide in $50 \mathrm{mM} \mathrm{NaCac}$ for 60 min. Samples were then washed in $50 \mathrm{mM} \mathrm{NaCac}$ three times and dehydrated in an 
75 ethanol gradient. After drying through a critical point drying apparatus (Polaron

76 E3000, Canada), samples were coated with gold in a sputter coater (Quorum Q150T

77 ES, Canada). SEM images were obtained using a FE-SEM-cold field emission

scanning electron microscope (Hitachi SU8010, Japan).

Transmission electron microscopy (TEM) was used to investigate cellular ultrastructure. Algal cells grown for $120 \mathrm{~h}$ were thoroughly washed using deionized water, prefixed in $2 \%$ glutaraldehyde, postfixed in $1 \%$ osmium tetroxide for $1 \mathrm{~h}$, and dehydrated through graded ethanol series. Samples were infiltrated with LR white resin 1:1 100\% EtOH for 3 hours, and 100\% LR white resin overnight. Samples were blocked into BEEM capsule and polymerized for 24 hours at 60 degrees. Ultrathin sections (90nm) were cut using an ultramicrotome (Leica, Canada). TEM images were obtained on a transmission electron microscopy (Hitachi HT7700, Japan).

\section{Elemental distribution for single cells through Synchrotron-based X-ray} fluorescence imaging

For the present XFI measurement, single algal cells were scanned using a polychromatic (pink) beam with a spot size of $3 \times 3 \mu \mathrm{m}$, a step size of $5 \mu \mathrm{m}$ and a dwell time of $5 \mathrm{~s}$ per data point. The cell deposited on the metal-free Lexan ${ }^{\mathrm{TM}}$ polycarbonate sheets were mounted on a sample holder and attached to a motorized stage. Synchrotron X-ray beam (pink) was incident at an angle of $90^{\circ}$ to the cell, while a Vortex ${ }^{\circledR}$ silicon drift detector (SDD), positioned $50 \mathrm{~mm}$ away from the cell at an angle of $45^{\circ}$ to the incident beam, was used for simultaneous collection of the emitted X-ray fluorescence signals of tested elements. The map size of approximately 
$160 \mu \mathrm{m} \times 160 \mu \mathrm{m}$ was selected for the elemental mapping of all algae samples. Three replicates of algae cells from each treatment were used for XFI to ensure reproducibility of the collected data.

\section{Oxidative stress}

Intracellular ROS was measured using 2,7-dichlorodihydrofluorescein diacetate (DCFH-DA, BioVision Incorporated, USA), which is an oxidation-sensitive fluorescent probe dye. ${ }^{4}$ Briefly, algal cells were grown for $120 \mathrm{~h}$ in the presence of 0 $4 \mathrm{mg} / \mathrm{L}$ triclosan with or without $5 \mathrm{mg} / \mathrm{L} \mathrm{P} 25$, harvested $(12,000 \times \mathrm{g}, 10 \mathrm{~min})$, washed and suspended in phosphate-buffered saline (PBS) containing $10 \mu \mathrm{M}$ DCFH-DA in dimethyl sulfoxide (DMSO), and then incubated for $30 \mathrm{~min}$ in the dark at $30{ }^{\circ} \mathrm{C}$. Algal cells were harvested, washed and lysed by sonication on ice for $2 \mathrm{~min}$ in $30 \mathrm{~s} / \mathrm{min}$ on/off cycles in the dark. $200 \mu \mathrm{L}$ of the supernatant was transferred to a 96 well plate and the fluorescence measured using a BioTek microplate reader (Winooski, VT, US; $\lambda \mathrm{ex}=485 \mathrm{~nm} ; \lambda \mathrm{em}=528 \mathrm{~nm})$. The assay was repeated a minimum of three times.

The mitochondrial dysfunction of exposed algal cells was measured by alteration of mitochondrial membrane potential (MMP, $\Delta \Psi \mathrm{m})$. Briefly, cells were collected by centrifugation $(12,000 \times \mathrm{g}, 10 \mathrm{~min})$ and washed by assay buffer. MMP was measured by the incorporation of a cationic florescent dye, tetramethylrhodamine, ethyl ester (TMRE) dye. Aliquots of approximately $1 \times 10^{5}-5 \times 10^{5}$ cells $/ \mathrm{mL}$ were stained with TMRE dye to a final concentration of $200 \mathrm{nM}$ at $37{ }^{\circ} \mathrm{C}$ for $30 \mathrm{~min}$. The dyed algal cells were washed three times by assay buffer to eliminate the excess dye. After 
124 washing, $100 \mu \mathrm{L}$ assay buffer was added and the fluorescence was measured using a

125 BioTek microplate reader (Winooski, VT, US; $\lambda \mathrm{ex}=549 \mathrm{~nm} ; \lambda \mathrm{em}=575 \mathrm{~nm}$ ).

126

127 The decomposition rate of hydrogen peroxide by catalase (CAT) was used to assay

128 the enzyme activity according to manufacturer's instruction (EnzyChrom Catalase

129 Assay Kit, BioAssay Systems Co, CA, USA). Briefly, cells were are homogenized in 130 cold PBS, and centrifuged for $10 \mathrm{~min}$ at $12,000 \mathrm{~g}$. A reaction mixture of $100 \mu \mathrm{L}$

131 containing $90 \mu \mathrm{L}$ of $50 \mu \mathrm{M} \mathrm{H}_{2} \mathrm{O}_{2}$, and $10 \mu \mathrm{L}$ algae supernatant was reacted for 30 min

132 at room temperature. $100 \mu \mathrm{L}$ detection reagent containing horse radish peroxidase

133 enzyme and dye reagent was added and incubated for 10 min. a mixture of $100 \mu \mathrm{L}$

134 was transferred to a 96 well plate and the fluorescence was measured using a BioTek

135 microplate reader (Winooski, VT, US; $\lambda \mathrm{ex}=530 \mathrm{~nm} ; \lambda \mathrm{em}=585 \mathrm{~nm}$ ). Catalase

136 activity was normalized to the unit amount of total protein to compare results between

137 different treatments.

138

139 


\section{RESULTS AND DISCUSSIONS}

\section{Verification of triclosan adsorption and P25 photocatalysis}

P25 is a mixture with the crystallographic forms of $78 \%$ anatase and $14 \%$ rutile. $^{5}$

TEM micrographs showed that P25 was spherical with diameters of 15-25 nm (Figure

S3). The mean hydrodynamic diameter of $\mathrm{P} 25$ after $48 \mathrm{~h}$ was determined to be 417.6

$\pm 22.23 \mathrm{~nm}$ when distributed in LEW and aggregation was observed. The zeta

potential of P25 was $-9.29 \pm 0.54 \mathrm{mV}$. The $\mathrm{pH}$ of LEW was 6.8 , higher than $6.3\left(\mathrm{p}_{\mathrm{zc}}\right.$ of

P25), which led to higher degree of deprotonation of surface hydroxyl groups, causing negatively charged surface of P25. The relatively low negative zeta potential may lead to the disequilibrium of chemicals in the surrounding water environment and result in charge heterogeneity, which was favorable for particle aggregation. ${ }^{6}$

In dark adsorption experiments, the average size of aggregated P25 showed an increasing trend with increasing concentrations of triclosan at $48 \mathrm{~h}$ (Figure S4). As well, there was a decreasing trend of zeta potential with increasing triclosan concentrations (Figure S5). Lower zeta potential corresponded to larger hydrodynamic diameter, which was favorable for the formation of aggregation. Thus, higher concentrations of triclosan resulted in the aggregation of P25 into larger aggregates. Since larger particle aggregates may be more difficult to enter the cells, it is hypothesized that larger P25 aggregates with higher levels of triclosan might not cause enhanced toxicity compared to that with triclosan-only exposed cells. But that one more thing should be considered is molecular concentration of triclosan also played a key role in toxicity. Because non-ionized triclsoan is known to be more toxic 
than its ionized form, ${ }^{7}$ the toxicity would be more serious when non-ionized triclosan is more than ionized triclsoan. Since triclosan has a pKa of $8.1,{ }^{8}$ most triclosan was in its molecular form at pH 6.8 in LEW. Thus, triclosan concentration seriously matters using LEW in our study.

Through adsorption studies in dark, the results showed triclosan adsorption onto P25 occurred from 0 to $24 \mathrm{~h}$, and it reached equilibrium after $24 \mathrm{~h}$. However, the adsorption of triclosan on P25 was so mild and the adsorption rate was less than $6 \%$ (data not shown). In Figure S6, it does not show any difference in terms of band intensities and frequencies when comparing ATR-FTIR spectra of P25 in the absence and in the presence of triclosan at both $5000 \mu \mathrm{g} / \mathrm{L}$ and $2500 \mu \mathrm{g} / \mathrm{L}$. It might be because the detection limit of ATR-FTIR was not enough to verify the adsorption of triclosan on P25 surface. The mild adsorption occurred; but it was too weak to be observed by ATR-FTIR.

Through triclosan photodegradation study (Figure S7), it can be seen that triclosan degradation under illumination was a slow process no matter it was due to photolysis (in the absence of P25) or photocatalysis (in the presence of P25) in visible light. Triclosan degradation rate in the presence of P25 was from 4 to $7 \%$, higher than that without $\mathrm{P} 25$ in $120 \mathrm{~h}$. The highest degradation rate was $6.47 \%$ in the presence of $\mathrm{P} 25$ in $120 \mathrm{~h}$. However, triclosan degradation rate in the presence of P25 was lower than that without P25 in 60h. It suggested that triclosan can be phototransformed by P25 in visible light, but with a low degradation rate. Normally, there are two principal catalytic phases of P25, anatase and rutile. Anatase P25 has a band gap of $3.2 \mathrm{eV} \mathrm{(385}$ $\mathrm{nm}$ ), and can not be active in visible light. ${ }^{9}$ Rutile has a smaller band gap of $3.0 \mathrm{eV}$ 
with excitation wavelengths extending into visible wavelength at $410 \mathrm{~nm} .{ }^{9}$ Thus, P25

can extend the photoactivity into visible wavelengths due to the existence of $14 \%$ rutile. It is also the reason that triclosan photodegradation could be enhanced in the presence of P25. However, only $14 \%$ rutile contributed to triclosan degradation, with hydroxyl radicals as the main species of ROS. ${ }^{10}$ Therefore, the degradation rate of triclosan in visible light is low.

\section{Dry weight analysis}

The size of Eremosphaera is too large to be counted by a hemocytometer. In order to estimate the size of the cultured algal population, dry weight measurement was performed. Figure S8 shows that dry weight exhibited dose-response relationship and had significant decreases in cells exposed to 4000 and $1000 \mu \mathrm{g} / \mathrm{L}$ triclosan. In the presence of P25, there was a significant decrease in cells exposed to $250 \mu \mathrm{g} / \mathrm{L}$ triclosan, while there were no significant changes of cells exposed to the same dose of triclosan in the absence of $\mathrm{P} 25$. Thus, the interaction can cause a significant reduction in dry weight at $250 \mu \mathrm{g} / \mathrm{L}$ triclosan, while pure triclosan can not cause a significant reduction until reaching $1000 \mu \mathrm{g} / \mathrm{L}$. The dry weight in the presence of P25 was higher than that in the absence of P25. Hartmann's study ${ }^{6}$ had the similar results that the growth of Pseudokrihneriella subcaptitata was stimulated by $2 \mathrm{mg} / \mathrm{L}$ P25. This effect is considered to be the hormesis response, which is a stimulatory effect caused by short-term exposure to a low dose of a toxicant. ${ }^{11}$ Interestingly, the dry weight of cells co-exposed to $15.625 \mu \mathrm{g} / \mathrm{L}$ triclosan and P25 was significantly higher than that of unexposed cells and cells only exposed to P25 and triclosan. It showed a stimulation of cell growth under such an interaction, with larger cell density than any individual 
exposure. Since the absolute value of dry weight exposed to the combinations was higher than that exposed to pure triclosan, P25 may alleviate the toxic effects of triclosan on algal biomass.

\section{Chlorophyll $\mathrm{a} / \mathrm{b}$ analysis}

The chlorophyll content is an indicator of photosynthetic ability. In Figure S9, in the absence of P25, there were significant decreases in chlorophyll a content to cells exposed to 1000 and $4000 \mu \mathrm{g} / \mathrm{L}$ triclosan, and significant decreases in chlorophyll b content to cells exposed to $4000 \mu \mathrm{g} / \mathrm{L}$ triclosan. Our previous study presented an inhibition in chlorophyll content of Chlorococcum sp. with increasing triclosan concentrations. ${ }^{12} \operatorname{Pan}^{13}$ also reported a significant decrease in chlorophyll content of

Chlamydomonas reinhardtii at $405.3 \mu \mathrm{g} / \mathrm{L}$ triclosan due to the damages in photopigments. Moreover, chlorophyll a/b content of cells only exposed to $5 \mathrm{mg} / \mathrm{L}$ P25 was much higher than that of unexposed cells. Similarly, in Middepogu's study, ${ }^{14}$ chlorophyll a content of Chlorella pyrenoidosa after $96 \mathrm{~h}$ exposure to $20 \mathrm{mg} / \mathrm{L}$ nano$\mathrm{TiO}_{2}$ was significant higher than that in no-exposed cells, and chlorophyll a content also increased from 20 to $45 \mathrm{nmol} / 10^{5}$ cells with increasing nano- $\mathrm{TiO}_{2}$ concentration from 0.1 to $10 \mathrm{mg} / \mathrm{L}$.

In the presence of $\mathrm{P} 25$, there were significant decreases in chlorophyll $\mathrm{a} / \mathrm{b}$ contents of cells exposed to triclosan in a range from 250 to $4000 \mu \mathrm{g} / \mathrm{L}$, while a significant increase was observed for cells exposed to $15.625 \mu \mathrm{g} / \mathrm{L}$ triclosan. Our previous study also found that there was a significant stimulation of chlorophyll contents in Asterococcus superbus and Eremosphaera viridis, when exposed to much lower 
triclosan concentrations of 0.56 or $0.0862 \mu \mathrm{g} / \mathrm{L} .{ }^{15}$ Such a significant stimulation in chlorophy $\mathrm{a} / \mathrm{b}$ is probably attributed to the hormesis caused by the interaction of low levels of triclosan and P25. The hormesis is the consequence of regulatory overcorrections by biosynthetic control mechanisms to low levels of inhibiting challenge, causing greater index than normal. ${ }^{16}$

\section{Variation of triclosan concentrations}

The concentration of triclosan was measured during the exposure period and the results are given in Figure S11. pH value was stable at 6.8 before and after exposure experiment. There was a trend that triclosan decreased rapidly at the first 3 days, and then decreased gradually at the rest 2 days in the absence and presence of P25. The final average concentrations of triclosan for all treatments were in the range of 80 $90 \%$ of initial concentrations, suggesting that triclosan was relatively stable during the exposure period.

The ratios of triclosan concentration variation in the presence of P25 to that in the absence of P25 in nonaqueous phase were shown in Table S2. On day 0 , the ratio was between 1 and 2, indicating the adsorption of triclosan in the presence of P25 was higher than that in the absence of P25. Triclosan reduction in the presence of P25 was attributed to the adsorption of both cells and P25 particles. On day 5, the ratio all decreased, indicating triclosan decline in the presence of P25 became lower than that in the absence of P25. At $4000 \mu \mathrm{g} / \mathrm{L}$ triclosan, the difference between two-day's ratios was the smallest, whereas at $15.625 \mu \mathrm{g} / \mathrm{L}$ triclosan, the difference was the largest. 
When triclosan concentration decreased, the growth became more stimulated, and led to the enlargement of cell population, increasing triclosan reduction.

\section{Responses of mitochondrion membrane potential}

Mitochondria is important not only in bioenergetics and metabolism, but also in cellular processes to environmental stressors. ${ }^{17}$ Mitochondrial membrane potential is often used for assessing mitochondrial function, as it relates to cells' capability to generate ATO by oxidative phosphorylation. ${ }^{18}$ Thus, $\Delta \Psi \mathrm{m}$ is a key indicator of cell health or injury.

Figure S13 shows the changes on mitochondrial membrane potential of treated cells. The absolute value of the mitochondrial depolarization in co-occurrence of P25 and triclosan was higher than that of only-triclosan-exposed treatments (data not shown). Triclosan at 15.625 and $62.5 \mu \mathrm{g} / \mathrm{L}$ with or without $\mathrm{P} 25$ had provoked mitochondrial depolarization but not significant. Thus, both P25 and low level triclosan with or without P25 could cause hormetic response in membrane potential depolarization.

At $250 \mu \mathrm{g} / \mathrm{L}$ triclosan, mitochondrial membrane potential decreased with or without P25, indicating deleterious effects on mitochondrium. But co-exposed cells did not have such significant decrease as triclosan-only exposed cells in this situation. At $1000 \mu \mathrm{g} / \mathrm{L}$ triclosan, co-exposed cells had a significant lower mitochondrial membrane potential than triclosan-only exposed cells, indicating the interactive effects beyond a certain amount of triclosan enhanced the inhibition in mitochondrial function. It has been proved that triclosan may impair the function of mitochondria, 
through uncoupling oxidative phosphorylation and disrupting mitochondrial membrane fluidity. ${ }^{19,20}$ However, P25 alleviated damages on mitochondrium at 250 $\mu \mathrm{g} / \mathrm{L}$ triclosan and intensified damages at $1000 \mu \mathrm{g} / \mathrm{L}$ triclosan. Thus, the interaction of P25 and a specific lower dose of triclosan led to antagonism in mitochondrial membrane potential. Once the cell membrane was damaged with elevating triclosan dose, P25 may enter the cells and attach to mitochondria, resulting in protein denaturation and cytoplasm flow-out. ${ }^{21}$ Hence, the interaction of P25 and a specific higher dose of triclosan caused synergetic damage on mitochondrial function.

At $4000 \mu \mathrm{g} / \mathrm{L}$ triclosan, there was significant lower mitochondrial membrane potential for cells in the presence and in the absence of $\mathrm{P} 25$, but there was no significant difference between those two situations. It indicated pure triclosan at such concentration caused serious cell apoptosis so that P25 had little additional effects on cells.

\section{Responses of catalase activity}

An increase in ROS production will eventually improve the production of antioxidant enzymes present inside the cells, such as $\mathrm{SOD}$ (acts on $\left.\mathrm{O}_{2}{ }^{-}\right)$, catalase (on $\mathrm{H}_{2} \mathrm{O}_{2}$ ), and GST (on the conjugation of glutathione). ${ }^{22} \mathrm{H}_{2} \mathrm{O}_{2}$ is generated through the catalysis of $\mathrm{O}_{2}{ }^{-}$during the photo respiration and $\beta$-oxidation of fatty acids. ${ }^{23}$ Catalase is a manganese or heme-containing enzyme, catalyzing the decomposition of $\mathrm{H}_{2} \mathrm{O}_{2}$ to water and oxygen ${ }^{24}$ Catalase plays an important role in the detoxification of active oxygen species generated by various types of environmental stress. ${ }^{23}$ Catalase activity 
313 has been frequently described in the mitochondria, and also been detected in

314 chloroplasts. $^{25}$

315

316 Figure S14 presents the catalase content of triclosan-exposed cells in the absence and 317 presence of P25. Significant catalase changes in Eremosphaera were observed when 318 cells were exposed to triclosan at $15.625 \mu \mathrm{g} / \mathrm{L}$ and beyond $1000 \mu \mathrm{g} / \mathrm{L}$. No matter with 319 or without P25, cells had a significant increase in catalase at $15.625 \mu \mathrm{g} / \mathrm{L}$ triclosan, 320 but a significant decrease at $4000 \mu \mathrm{g} / \mathrm{L}$ triclosan. At $15.625 \mu \mathrm{g} / \mathrm{L}$ triclosan in the 321 absence and presence of P25, catalase content had been stimulated by 133 and $155 \%$, 322 respectively, compared to its corresponding control. At $4000 \mu \mathrm{g} / \mathrm{L}$ triclosan in the 323 absence and presence of P25, catalase content had been inhibited by 20 and $15 \%$, 324 respectively, compared to its corresponding control. What's more, there was no 325 significant difference between P25-only exposed cells and untreated cells, indicating 326 P25 did not induce excess catalase. However, the distinctions between cells in the 327 absence and presence of P25 at 250 and $1000 \mu \mathrm{g} / \mathrm{L}$ triclosan were significant. Thus, 328 although $5 \mathrm{mg} / \mathrm{L}$ P25 did not cause significant changes in catalase content, its 329 interaction with triclosan did. The main reason was attributed to triclosan and its 330 concentrations. 


\section{List of figures and tables}

Figure S1. The microscopic image of freshwater green alga Eremosphaera.

Figure S2. (A) The Canadian light source, (B) Bruker Vertex 70v Interferometer / Hyperion 3000 IR Microscope on Mid-IR beamline, (C) Workstation on VESPERS beamline.

Figure S3. TEM micrograph of P25.

Figure S4. Hydrodynamic diameter for $5 \mathrm{mg} / \mathrm{L}$ P25 in the presence of triclosan $(n=3)$.

Figure S5. Zeta potential for $5 \mathrm{mg} / \mathrm{L} \mathrm{P} 25$ in the presence of triclosan $(\mathrm{n}=3)$.

Figure S6. ATR-FTIR spectra of pure triclosan, P25, P25 - 5000 $\mu \mathrm{g} / \mathrm{L}$ triclosan, and $\mathrm{P} 25-2500 \mu \mathrm{g} / \mathrm{L}$ triclosan.

Figure S7. Degradation rate of triclosan in the absence and presence of $5 \mathrm{mg} / \mathrm{L} \mathrm{P} 25$ in LEW.

Figure S8. Dry weight of Eremosphaera exposed to triclosan in the absence and presence of $5 \mathrm{mg} / \mathrm{L}$ P25 (n=3).

Figure S9. The variation of chlorophyll content in cultures exposed to triclosan in the absence and presence of $5 \mathrm{mg} / \mathrm{L}$ P25 (n=3). (A) chlorophyll a, (B) chlorophyll b.

Figure S10. TEM images of Eremosphaera. (A) (B) Cells exposed to $1000 \mu \mathrm{g} / \mathrm{L}$ triclosan; (C) (D) Cells co-exposed to $5 \mathrm{mg} / \mathrm{L}$ P25 and $1000 \mu \mathrm{g} / \mathrm{L}$ triclosan.

Figure S11. Observed triclosan concentration in algal media.

Figure S12. Partial investigation of the distribution of multi-elements in an individual algal cell. (A) Cells exposed to $250 \mu \mathrm{g} / \mathrm{L}$ triclosan; (B) Cells exposed to $5 \mathrm{mg} / \mathrm{L} \mathrm{P} 25$; (C) Cells co-exposed to $5 \mathrm{mg} / \mathrm{L} \mathrm{P} 25$ and $62.5 \mu \mathrm{g} / \mathrm{L}$ triclosan; (D) Cells co-exposed to $5 \mathrm{mg} / \mathrm{L} \mathrm{P} 25$ and $250 \mu \mathrm{g} / \mathrm{L}$ triclosan.

Figure S13. Mitochondrial depolarization of algal cells exposed to triclosan in the absence and presence of $5 \mathrm{mg} / \mathrm{L}$ P25 (n=3). 
363

364

365

366

367

368

369

370

Figure S14. Catalase of algal cells exposed to triclosan in the absence and presence of $5 \mathrm{mg} / \mathrm{L} \mathrm{P} 25(\mathrm{n}=3)$.

Table S1. Triclosan given with its molecular information, water solubility and application area.

Table S2. The ratios of triclosan concentration variation in the presence of P25 to that in the absence of P25 in nonaqueous phase. 


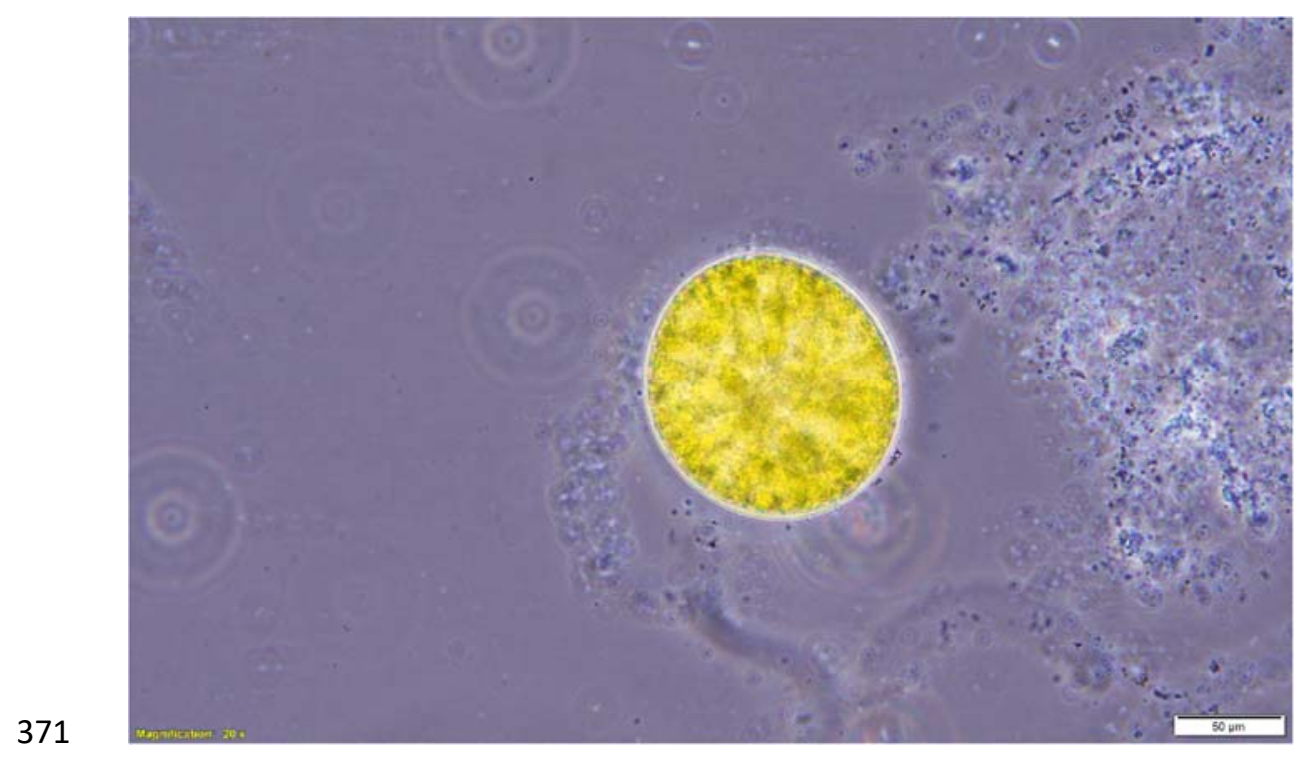

372 Figure S1. The microscopic image of freshwater green alga Eremosphaera. 
(A)

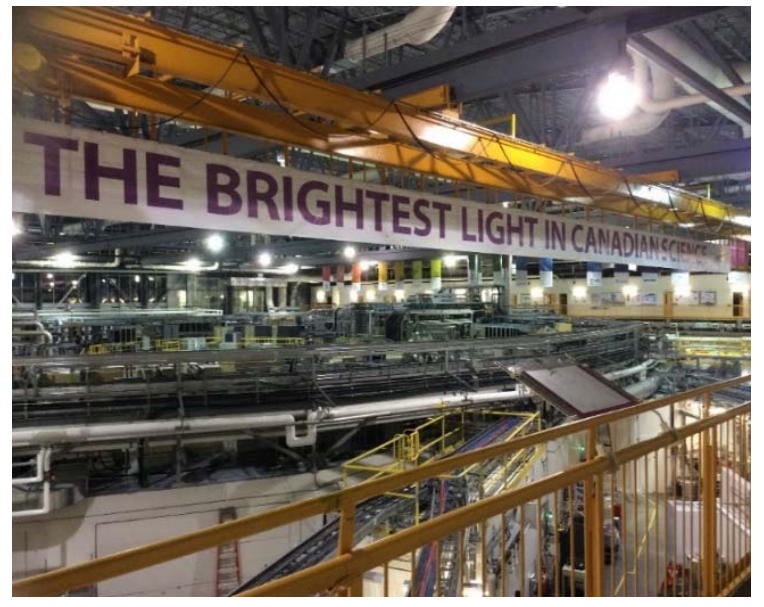

(C)

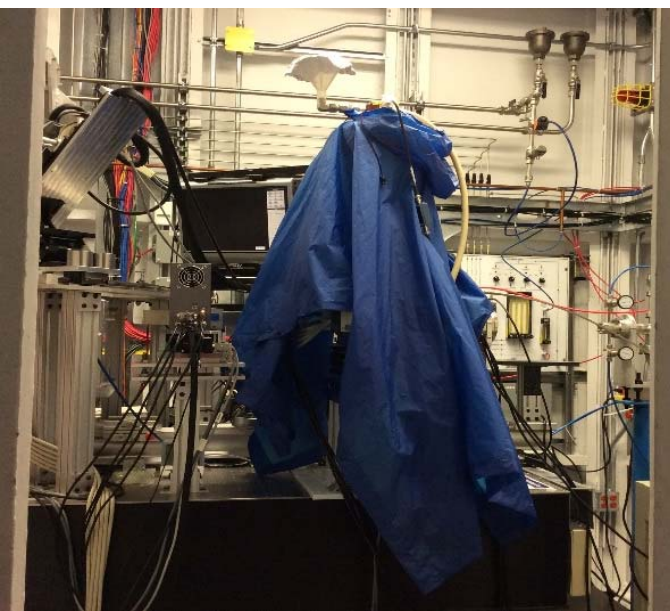

(B)

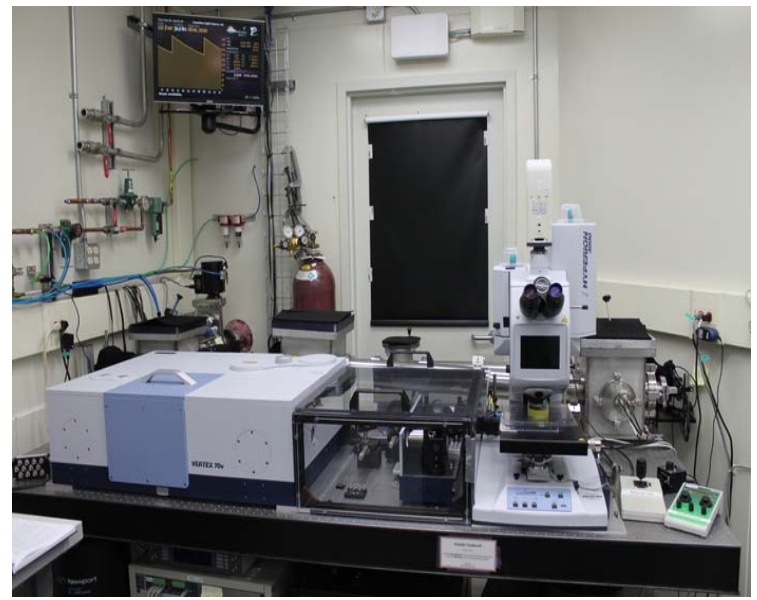

Figure S2. (A) The Canadian light source, (B) Bruker Vertex 70v Interferometer / Hyperion 3000 IR Microscope on Mid-IR beamline, (C) Workstation on VESPERS beamline. 


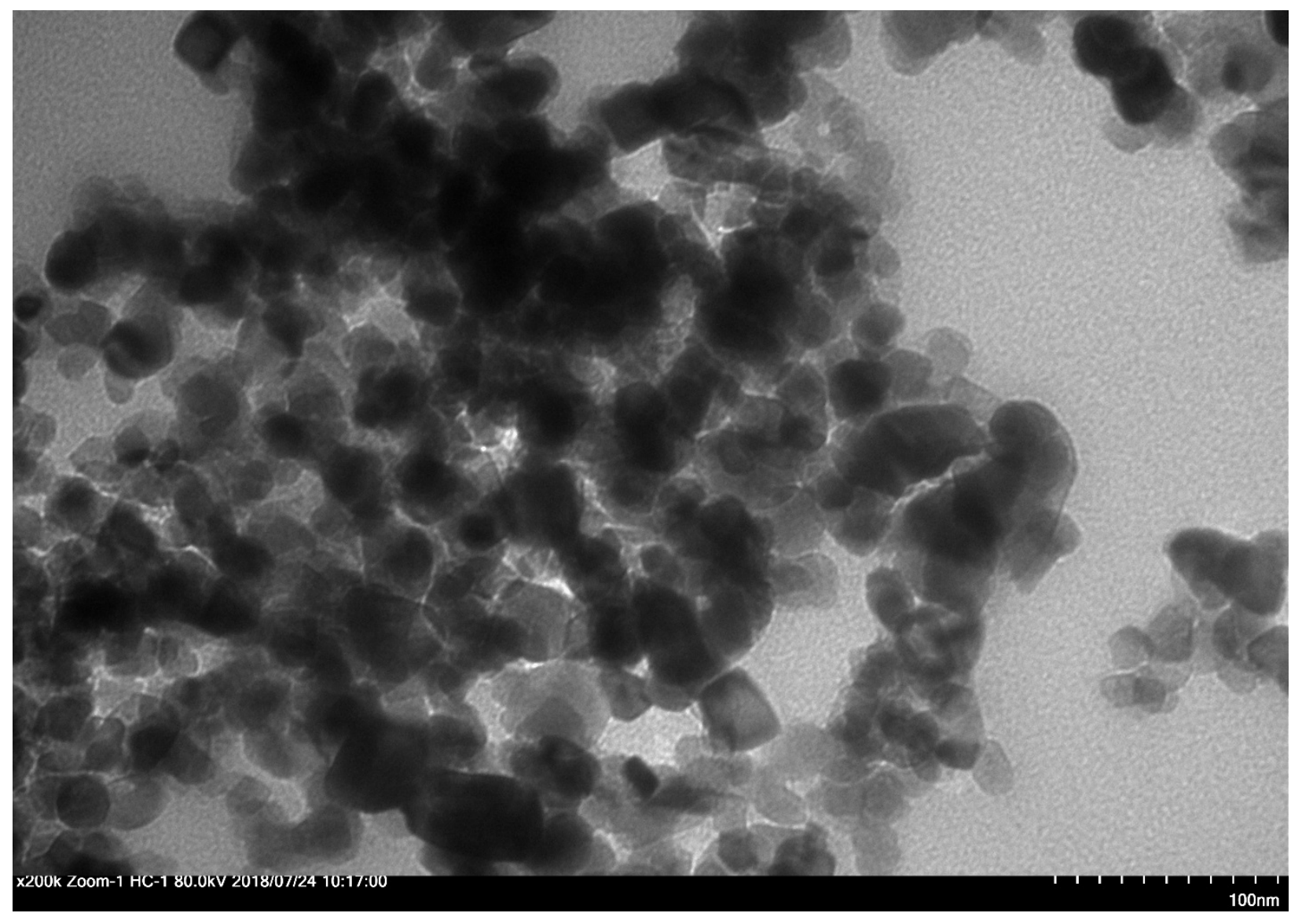

Figure S3. TEM micrograph of P25. 


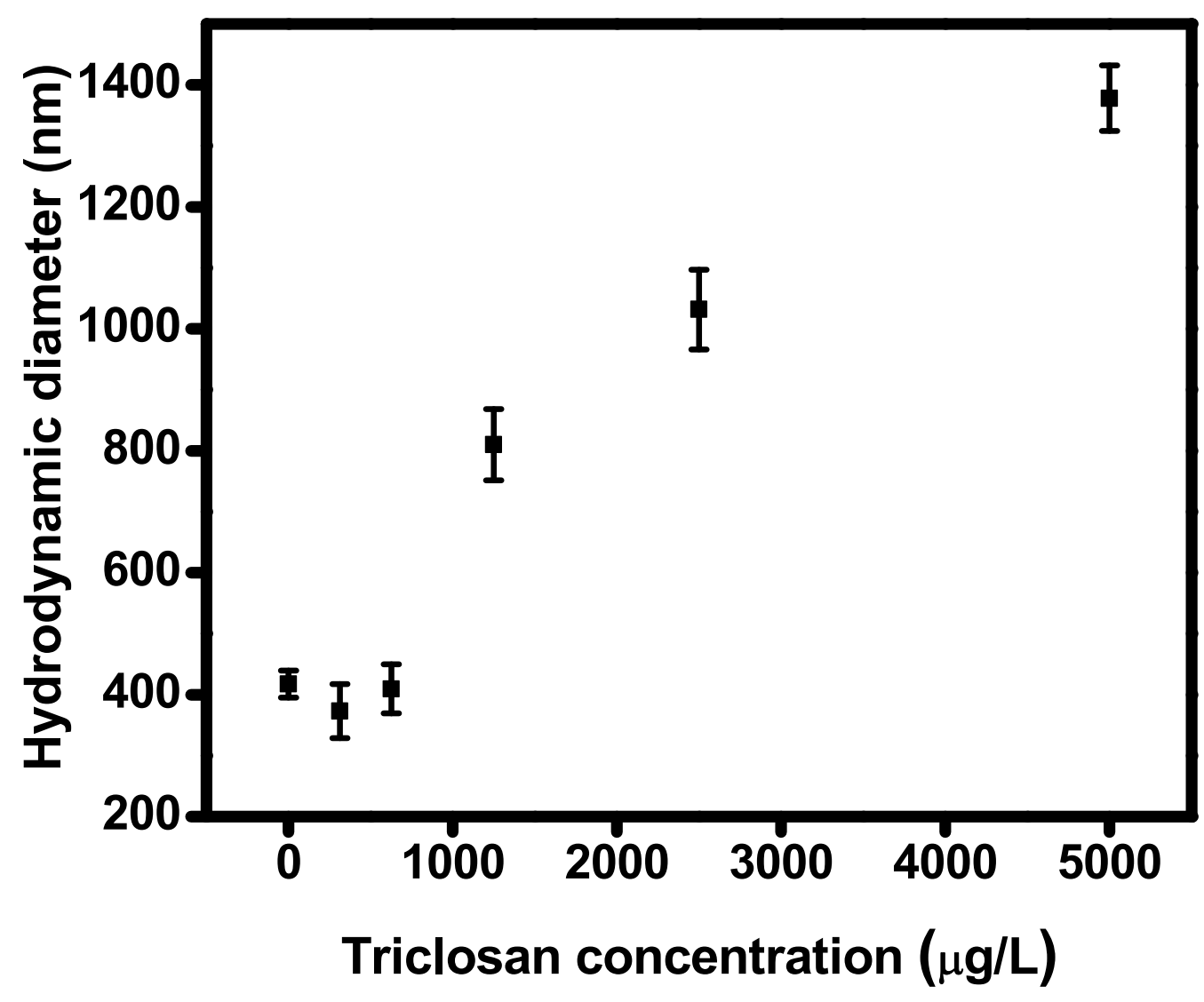

Figure S4. Hydrodynamic diameter for $5 \mathrm{mg} / \mathrm{L}$ P25 in the presence of triclosan $(\mathrm{n}=3)$. 


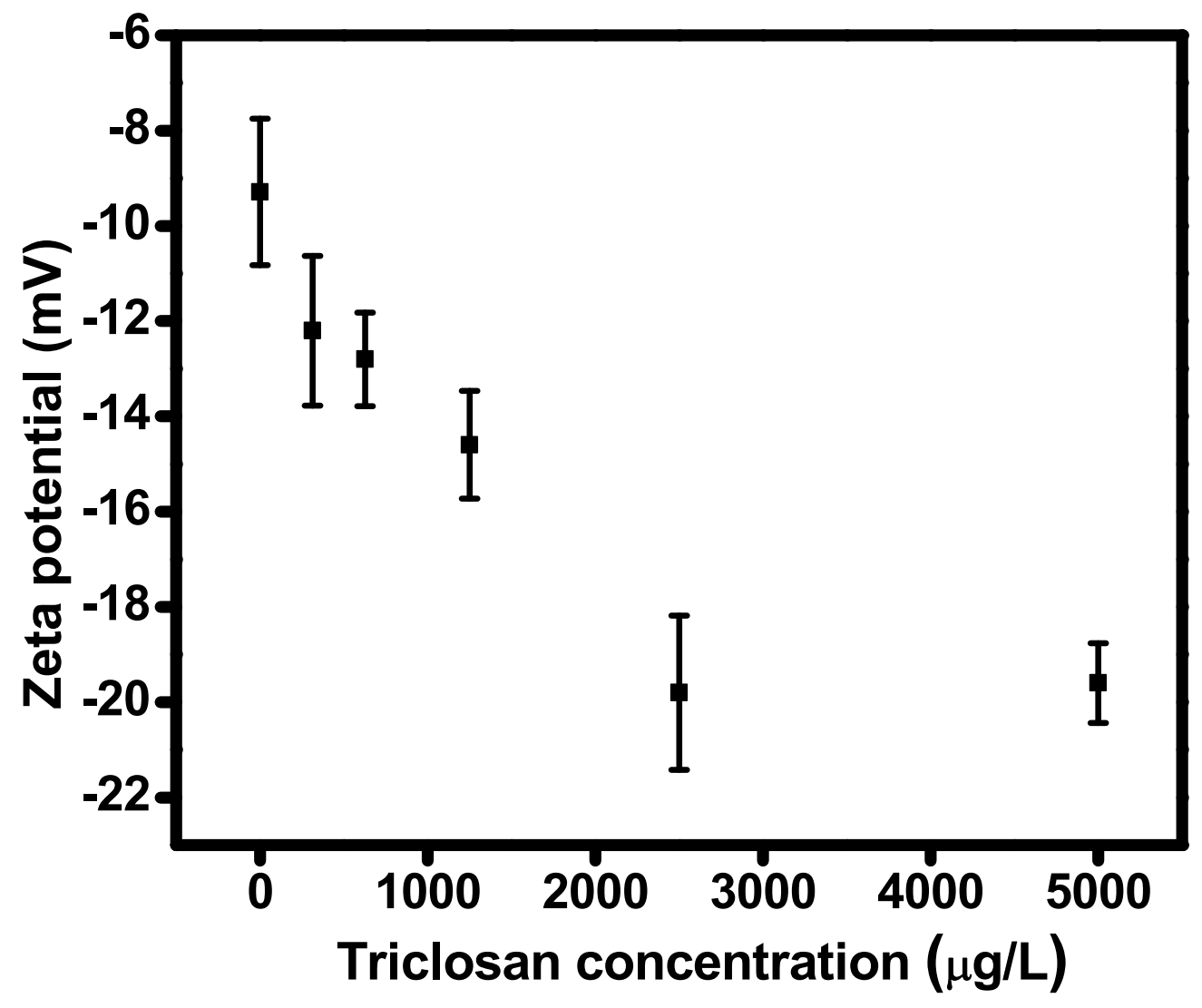

Figure S5. Zeta potential for $5 \mathrm{mg} / \mathrm{L}$ P25 in the presence of triclosan $(\mathrm{n}=3)$. 


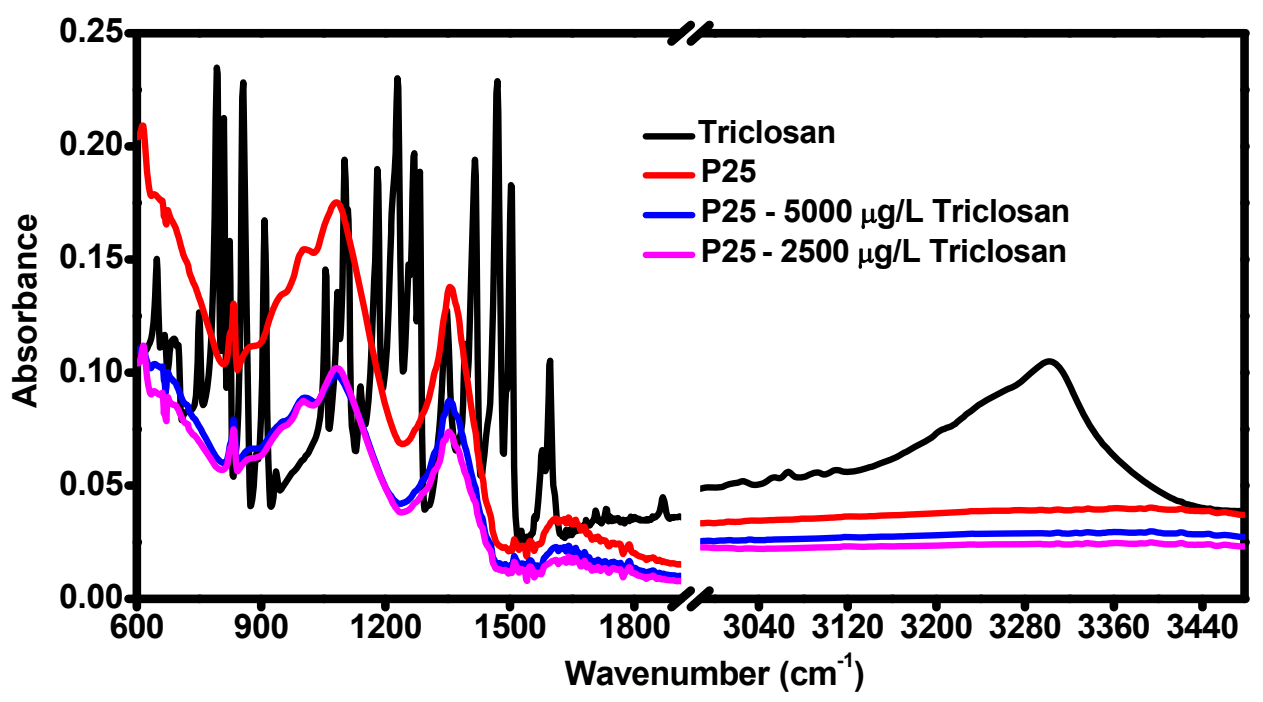

Figure S6. ATR-FTIR spectra of pure triclosan, P25, P25 - 5000 $\mu \mathrm{g} / \mathrm{L}$ triclosan, and P25 - 2500 $\mu \mathrm{g} / \mathrm{L}$ triclosan. 


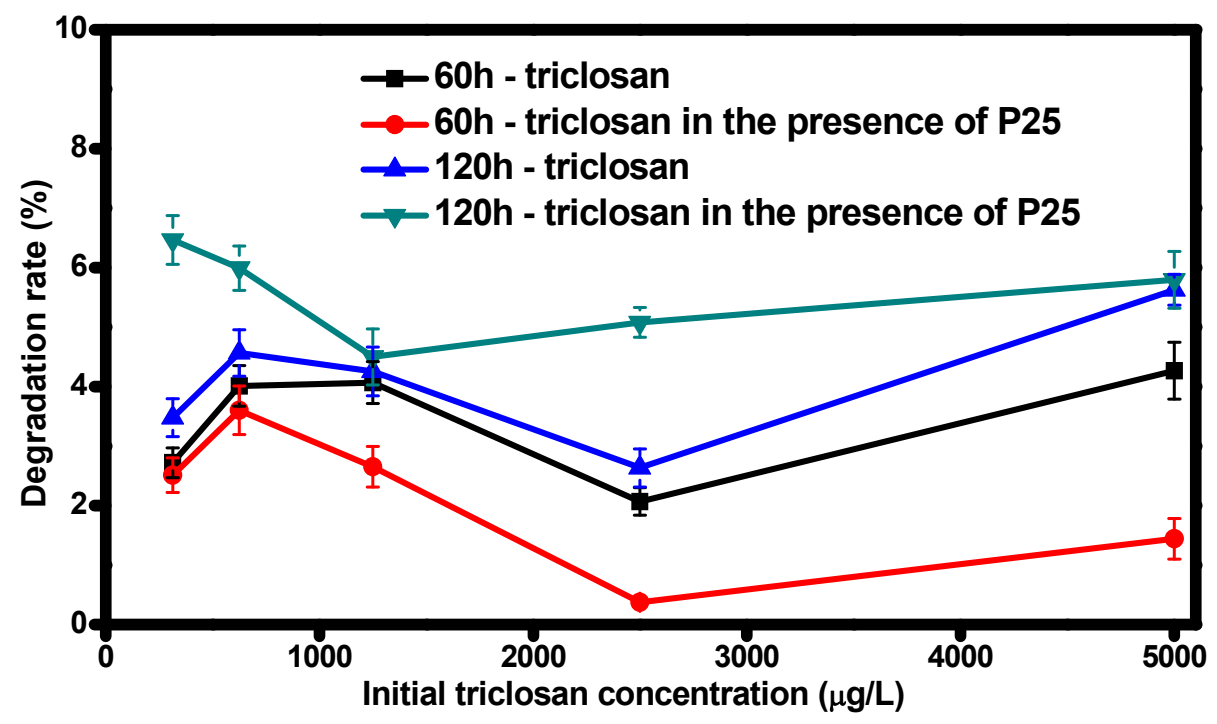

Figure S7. Degradation rate of triclosan in the absence and presence of $5 \mathrm{mg} / \mathrm{L} \mathrm{P} 25$ in LEW. 


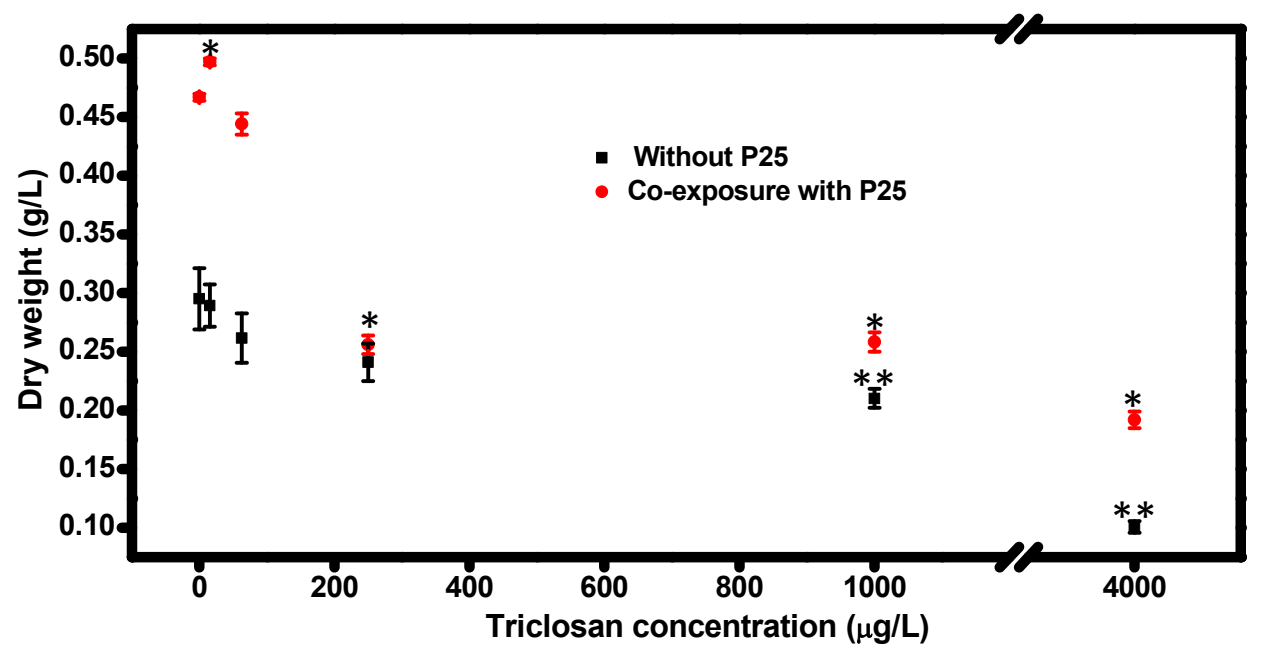

Figure S8. Dry weight of Eremosphaera exposed to triclosan in the absence and presence of 5 $\mathrm{mg} / \mathrm{L} \mathrm{P25}(\mathrm{n}=3)$.

Note: “*” represents results that were significantly different from the untreated control $(\mathrm{p}<$ $0.05)$; “**” represents results that were significantly different from the control only exposed to 5 $\mathrm{mg} / \mathrm{L} \mathrm{P} 25(\mathrm{p}<0.05)$. 


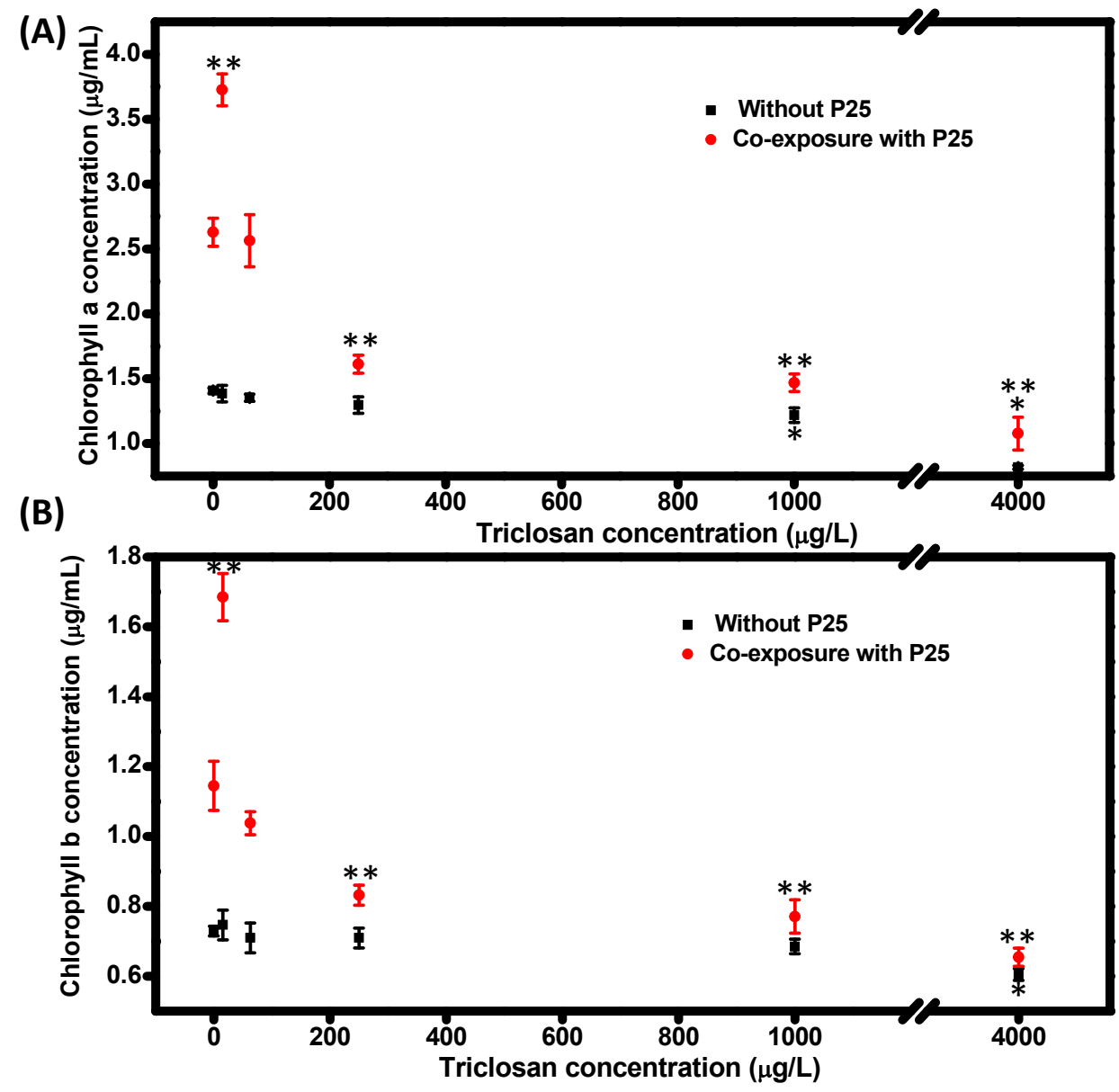

Figure S9. The variation of chlorophyll content in cultures exposed to triclosan in the absence and presence of $5 \mathrm{mg} / \mathrm{L} \mathrm{P25}(\mathrm{n}=3)$. (A) chlorophyll a, (B) chlorophyll b.

Note: “*” represents results that were significantly different from the untreated control $(\mathrm{p}<$ $0.05) ;$ “**” represents results that were significantly different from the control only exposed to 5 $\mathrm{mg} / \mathrm{L} \mathrm{P} 25(\mathrm{p}<0.05)$. 


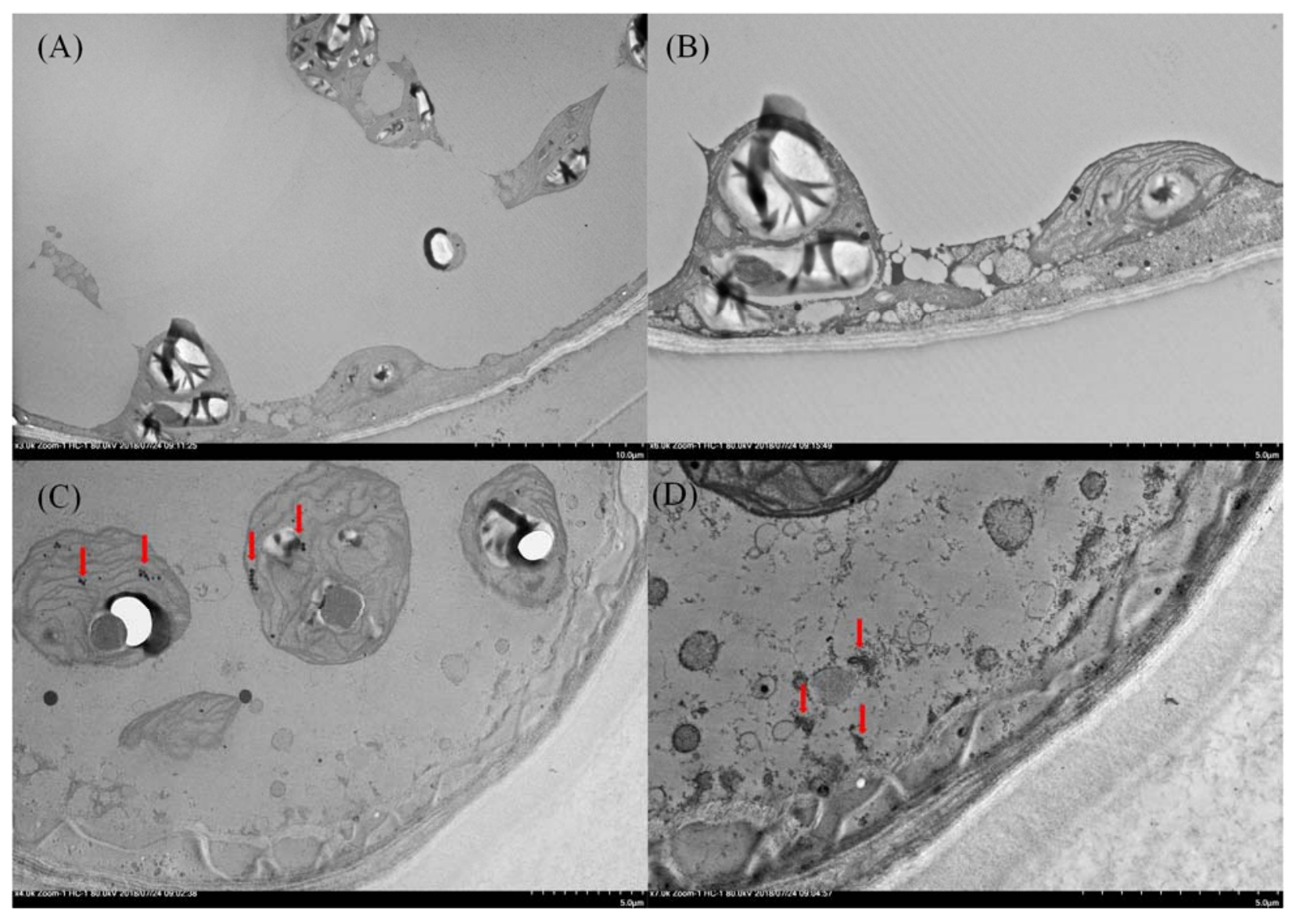

Figure S10. TEM images of Eremosphaera. (A) (B) Cells exposed to $1000 \mu \mathrm{g} / \mathrm{L}$ triclosan; (C)

(D) Cells co-exposed to $5 \mathrm{mg} / \mathrm{L}$ P25 and $1000 \mu \mathrm{g} / \mathrm{L}$ triclosan.

Note: Red arrow indicated P25 inside the cells. 


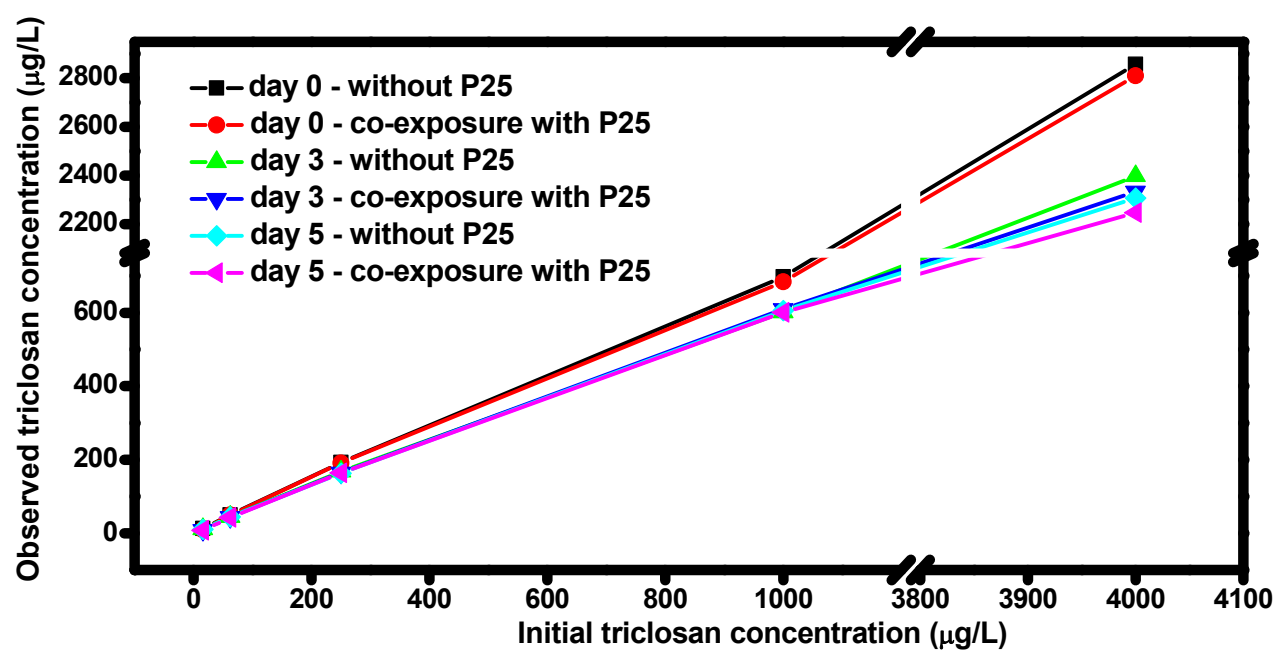

Figure S11. Observed triclosan concentration in algal media. 
(A)

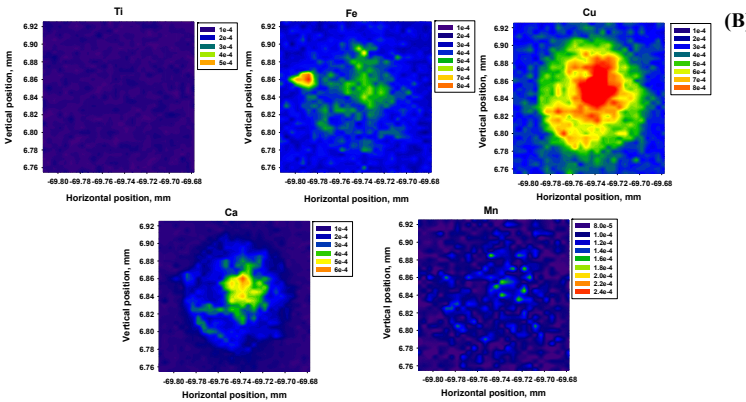

(C)
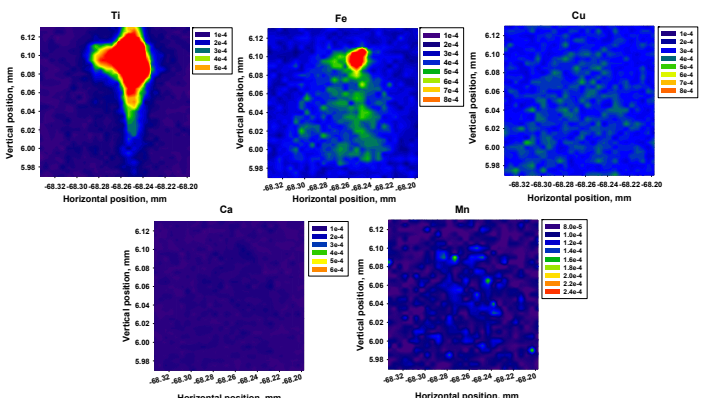

(D)

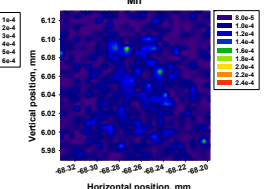

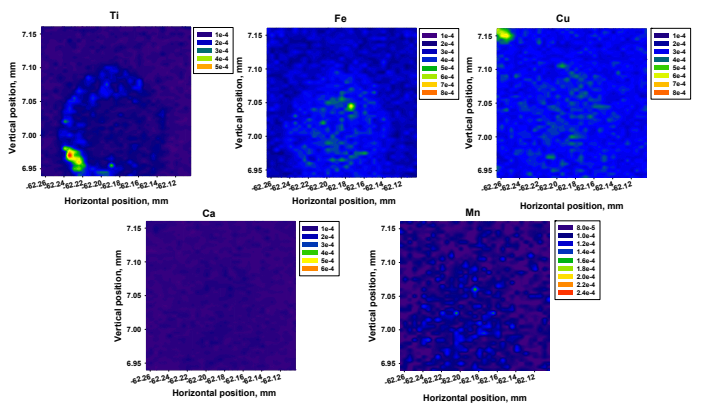

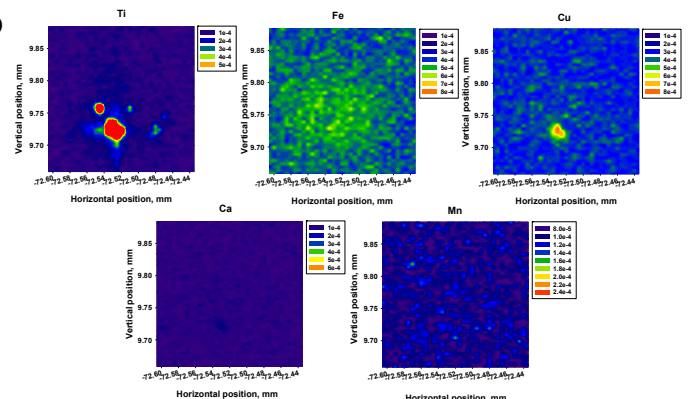

Figure S12. Partial investigation of the distribution of multi-elements in an individual algal cell.

(A) Cells exposed to $250 \mu \mathrm{g} / \mathrm{L}$ triclosan; (B) Cells exposed to $5 \mathrm{mg} / \mathrm{L}$ P25; (C) Cells co-exposed to $5 \mathrm{mg} / \mathrm{L} \mathrm{P} 25$ and $62.5 \mu \mathrm{g} / \mathrm{L}$ triclosan; (D) Cells co-exposed to $5 \mathrm{mg} / \mathrm{L} \mathrm{P} 25$ and $250 \mu \mathrm{g} / \mathrm{L}$ triclosan. 


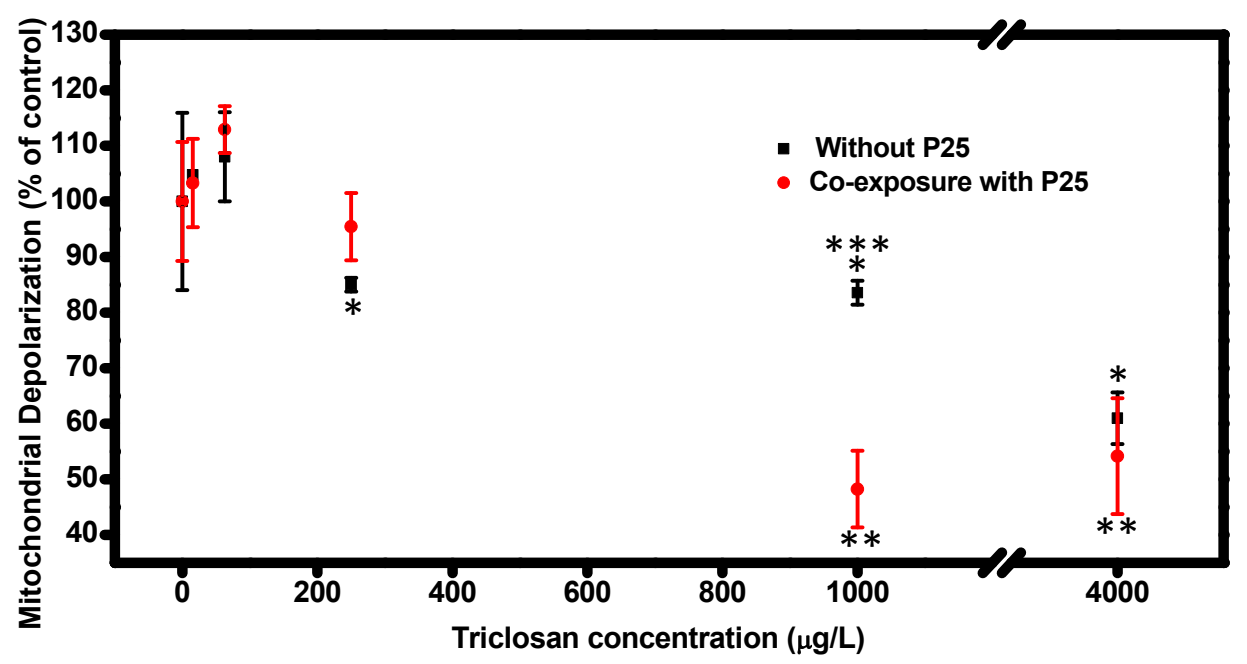

Figure S13. Mitochondrial depolarization of algal cells exposed to triclosan in the absence and presence of $5 \mathrm{mg} / \mathrm{L}$ P25 (n=3).

Note: “*” represents results that were significantly different from the untreated control $(\mathrm{p}<$ $0.05) ;$ “**” represents results that were significantly different from the control only exposed to 5 $\mathrm{mg} / \mathrm{L}$ P25 $(\mathrm{p}<0.05)$. “***” represents results that were significantly different in treatments between in the absence and in the presence of $5 \mathrm{mg} / \mathrm{L} \mathrm{P} 25(\mathrm{p}<0.05)$. 


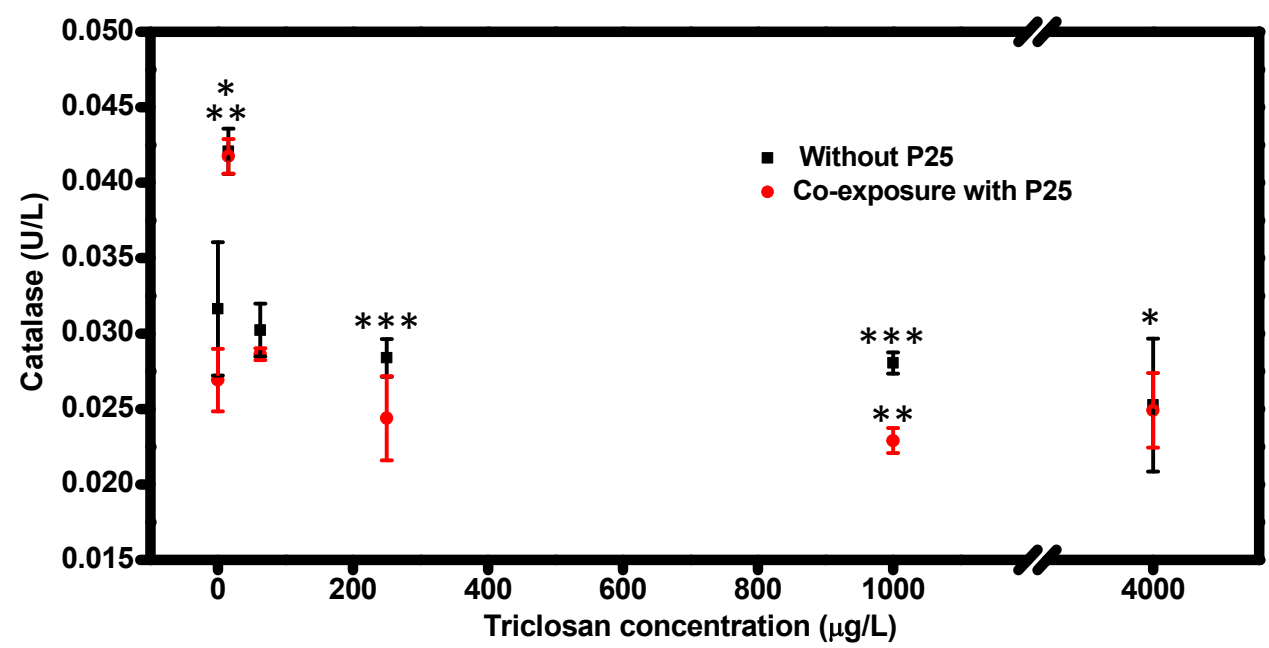

Figure S14. Catalase of algal cells exposed to triclosan in the absence and presence of $5 \mathrm{mg} / \mathrm{L}$ P25 (n=3).

Note: "*" represents results that were significantly different from the untreated control $(\mathrm{p}<$ $0.05) ;$ “**” represents results that were significantly different from the control only exposed to 5 $\mathrm{mg} / \mathrm{L}$ P25 $(\mathrm{p}<0.05)$. “***” represents results that were significantly different in treatments between in the absence and in the presence of $5 \mathrm{mg} / \mathrm{L} \mathrm{P} 25(\mathrm{p}<0.05)$. 
Table S1. Triclosan given with its molecular information, water solubility and application area. ${ }^{\text {a }}$

\begin{tabular}{|c|c|}
\hline Characteristics & Triclosan \\
\hline Molecular Formula & $\mathrm{C}_{12} \mathrm{H}_{7} \mathrm{Cl}_{3} \mathrm{O}_{2}$ \\
\hline Molecular Structure & \\
\hline MW (g/mol) & 289.54 \\
\hline Solubility (mg/L) & 10 \\
\hline $\mathrm{pKa}$ & 8.1 \\
\hline Application & Antimicrobial agent \\
\hline
\end{tabular}

aThis table has been published in Xin et al. 2018. ${ }^{12}$

Reprinted from Environmental Pollution, Volume 226, Xiaying Xin, Guohe Huang, Xia Liu, Chunjiang An, Yao Yao, Harold Weger, Peng Zhang, Xiujuan Chen, Molecular toxicity of triclosan and carbamazepine to green algae Chlorococcum sp.: A single cell view using synchrotron-based Fourier transform infrared spectromicroscopy, 12-20, Copyright (2017), with permission from Elsevier. 
Table S2. The ratios of triclosan concentration variation in the presence of P25 to that in the absence of P25 in nonaqueous phase.

\begin{tabular}{lll}
\hline Triclosan concentration & Day 0 & Day 5 \\
$(\mu \mathrm{g} / \mathrm{L})$ & & \\
\hline 4000 & 1.04180 & 1.03523 \\
1000 & 1.04679 & 1.02336 \\
250 & 1.05003 & 1.02900 \\
62.5 & 1.05307 & 1.01713 \\
15.625 & 2.20821 & 1.47657 \\
\hline
\end{tabular}




\section{References}

(1) Wen, Y.; Chen, H.; Shen, C.; Zhao, M.; Liu, W. Enantioselectivity tuning of chiral herbicide dichlorprop by copper: roles of reactive oxygen species. Environ. Sci. Technol. 2011, 45, (11), 47784784.

(2) White, E.; Payne, G. Chlorophyll production, in response to nutrient additions, by the algae in Lake Rotorua water. New Zeal. J. Mar. Fresh. 1978, 12, (2), 131-138.

(3) Jeffrey, S. t.; Humphrey, G. New spectrophotometric equations for determining chlorophylls a, b, c 1 and c 2 in higher plants, algae and natural phytoplankton. Biochem. Physiol. Pflanz. 1975, 167, (2), 191194.

(4) Zhao, J.; Cao, X.; Liu, X.; Wang, Z.; Zhang, C.; White, J. C.; Xing, B. Interactions of CuO nanoparticles with the algae Chlorella pyrenoidosa: adhesion, uptake, and toxicity. Nanotoxicology 2016, 10, (9), 1297-1305.

(5) Bickley, R. I.; Gonzalez-Carreno, T.; Lees, J. S.; Palmisano, L.; Tilley, R. J. A structural investigation of titanium dioxide photocatalysts. J. Solid State Chem. 1991, 92, (1), 178-190.

(6) Hartmann, N.; Von der Kammer, F.; Hofmann, T.; Baalousha, M.; Ottofuelling, S.; Baun, A. Algal testing of titanium dioxide nanoparticles - testing considerations, inhibitory effects and modification of cadmium bioavailability. Toxicology 2010, 269, (2-3), 190-197.

(7) Orvos, D. R.; Versteeg, D. J.; Inauen, J.; Capdevielle, M.; Rothenstein, A.; Cunningham, V. Aquatic toxicity of triclosan. Environ. Toxicol. Chem. 2002, 21, (7), 1338-1349.

(8) Singer, H.; Müller, S.; Tixier, C.; Pillonel, L. Triclosan: occurrence and fate of a widely used biocide in the aquatic environment: field measurements in wastewater treatment plants, surface waters, and lake sediments. Environ. Sci. Technol. 2002, 36, (23), 4998-5004.

(9) Hurum, D. C.; Agrios, A. G.; Gray, K. A.; Rajh, T.; Thurnauer, M. C. Explaining the enhanced photocatalytic activity of Degussa P25 mixed-phase $\mathrm{TiO}_{2}$ using EPR. J. Phys. Chem. B 2003, 107, (19), 4545-4549.

(10) Rafqah, S.; Wong-Wah-Chung, P.; Nelieu, S.; Einhorn, J.; Sarakha, M. Phototransformation of triclosan in the presence of $\mathrm{TiO}_{2}$ in aqueous suspension: Mechanistic approach. Appl. Catal. B. Environ. 2006, 66, (1-2), 119-125.

(11) Calabrese, E. J.; Iavicoli, I.; Calabrese, V. Hormesis: why it is important to biogerontologists. Biogerontology 2012, 13, (3), 215-235.

(12) Xin, X.; Huang, G.; Liu, X.; An, C.; Yao, Y.; Weger, H.; Zhang, P.; Chen, X. Molecular toxicity of triclosan and carbamazepine to green algae Chlorococcum sp.: A single cell view using synchrotronbased Fourier transform infrared spectromicroscopy. Environ. Pollut. 2017, 226, 12-20.

(13) Pan, C.-G.; Peng, F.-J.; Shi, W.-J.; Hu, L.-X.; Wei, X.-D.; Ying, G.-G. Triclosan-induced transcriptional and biochemical alterations in the freshwater green algae Chlamydomonas reinhardtii. Ecotoxicol. Environ. Safety 2018, 148, 393-401.

(14) Middepogu, A.; Hou, J.; Gao, X.; Lin, D. Effect and mechanism of TiO 2 nanoparticles on the photosynthesis of Chlorella pyrenoidosa. Ecotoxicol. Environ. Safety 2018, 161, 497-506.

(15) Xin, X.; Huang, G.; An, C.; Raina-Fulton, R.; Weger, H. Insights into Long-term Toxicity of Triclosan to Freshwater Green Algae in Lake Erie. Environ. Sci. Technol. 2019.

(16) Stebbing, A. Hormesis - the stimulation of growth by low levels of inhibitors. Sci. Total Environ. 1982, 22, (3), 213-234.

(17) González-Pleiter, M.; Rioboo, C.; Reguera, M.; Abreu, I.; Leganés, F.; Cid, Á.; Fernández-Piñas, F. Calcium mediates the cellular response of Chlamydomonas reinhardtii to the emerging aquatic pollutant Triclosan. Aquat. Toxicol. 2017, 186, 50-66.

(18) Perry, S. W.; Norman, J. P.; Barbieri, J.; Brown, E. B.; Gelbard, H. A. Mitochondrial membrane potential probes and the proton gradient: a practical usage guide. Biotechniques 2011, 50, (2), 98-115. (19) Franz, S.; Altenburger, R.; Heilmeier, H.; Schmitt-Jansen, M. What contributes to the sensitivity of microalgae to triclosan? Aquat. Toxicol. 2008, 90, (2), 102-108. 
(20) Newton, A. P. N.; Cadena, S. M. S.; Rocha, M. E. M.; Carnieri, E. G. S.; De Oliveira, M. B. M. Effect of triclosan (TRN) on energy-linked functions of rat liver mitochondria. Toxicol. Lett. 2005, 160, (1), 49-59.

(21) Hou, J.; Wang, L.; Wang, C.; Zhang, S.; Liu, H.; Li, S.; Wang, X. Toxicity and mechanisms of action of titanium dioxide nanoparticles in living organisms. J. Environ. Sci. 2018.

(22) Roy, B.; Chandrasekaran, H.; Krishnan, S. P.; Chandrasekaran, N.; Mukherjee, A. UVA preirradiation to P25 titanium dioxide nanoparticles enhanced its toxicity towards freshwater algae Scenedesmus obliquus. Environ. Sci. Pollut. Res. 2018, 1-14.

(23) Cohen, G.; Heikkila, R. E. The generation of hydrogen peroxide, superoxide radical, and hydroxyl radical by 6-hydroxydopamine, dialuric acid, and related cytotoxic agents. J. Biol. Chem. 1974, 249, (8), 2447-2452.

(24) Peng, Y.; Luo, Y.; Nie, X.-P.; Liao, W.; Yang, Y.-F.; Ying, G.-G. Toxic effects of Triclosan on the detoxification system and breeding of Daphnia magna. Ecotoxicology 2013, 22, (9), 1384-1394.

(25) Mhamdi, A.; Queval, G.; Chaouch, S.; Vanderauwera, S.; Van Breusegem, F.; Noctor, G. Catalase function in plants: a focus on Arabidopsis mutants as stress-mimic models. J. Exp. Bot. 2010, 61, (15), 4197-4220. 